\title{
Parathyroidectomy After Kidney Transplantation: A Single-Center Experience
}

\author{
Ergün Parmaksız, (10) Meral Meşe, (1) Serkan Feyyaz Yalın,

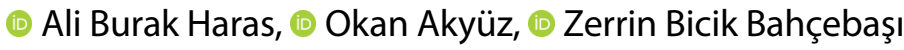

Department of Nephrology, University of Health Sciences Kartal Dr. Lütfi Kırdar Training and Research Hospital, İstanbul, Turkey

Submitted: 12.08 .2018 Accepted: 27.08.2018

Correspondence: Ergün Parmaksız, SBÜ Kartal Dr. Lütfi Kırdar Eğitim ve Araştırma Hastanesi, Nefroloji Kliniği, İstanbul, Turkey E-mail: drergnprmksz@hotmail.com

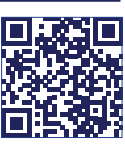

Keywords: Calcium; parathyroidectomy; renal transplantation.

\begin{abstract}
Objective: Even after successful kidney transplantation, $10 \%$ to $50 \%$ of kidney transplant recipients have persistent hyperparathyroidism. Parathyroidectomy (PTX) has been reported to be associated with deterioration of renal function and reduced graft survival. The aim of this single-center, retrospective study was to analyze the long-term effect of PTX on calcium, phosphorus, and parathyroid hormone (PTH) levels, as well as the estimated glomerular filtration rate (eGFR), in renal transplantation patients who underwent PTX.
\end{abstract}

Methods: The study population consisted of I54 patients followed between January 2014 and December 2017, 9 of whom underwent PTX. The median PTH, calcium, phosphorus, and eGFR values were recorded before and after PTX.

Results: The median preparathyroidectomy PTH, calcium, phosphorus, and eGFR values were $311.57 \mathrm{pg} / \mathrm{mL}$, $11.02 \mathrm{mg} / \mathrm{dL}, 2.35 \mathrm{mg} / \mathrm{dL}$, and $90.88 \mathrm{~mL} /$ minute, respectively. When compared with the baseline figures, there was a decrease in PTH $(311.5 \mathrm{vs} .147 .5 \mathrm{pg} / \mathrm{mL}$; $\mathrm{p}=0.015)$, calcium ( II.02 vs. $9.01 \mathrm{mg} / \mathrm{dL} ; \mathrm{p}=0.017)$, and eGFR ( $90.88 \mathrm{vs.} 75.44 \mathrm{~mL} / \mathrm{minute}$; $\mathrm{p}=0.008)$, and an increase in the phosphorus level ( $2.35 \mathrm{vs} .3 .4 \mathrm{mg} / \mathrm{dL} ; \mathrm{p}=0.06)$ I month after surgery. The eGFR returned to the baseline rate I year after surgery $(90.88 \mathrm{vs} .79 .39 \mathrm{~mL} /$ minute; $p=0.1 \mathrm{I})$.

Conclusion: PTX in renal transplant recipients appears to be a safe procedure. Although renal function deteriorates in the acute period following PTX, long-term stabilization occurs.

\section{INTRODUCTION}

It is supposed that hyperparathyroidism (HPT) improves in the first year after renal transplantation. ${ }^{[l]}$ Nevertheless, $10 \%-50 \%$ of the cases still show persistent HPT even after a successful renal transplantation, ${ }^{[2]}$ and its occurrence is thought to be related to the period elapsed under dialysis prior to transplantation. ${ }^{[3]}$ Although HPT has been recognized after a long time from renal transplantation, management of the disease is still controversial. ${ }^{[4]}$ Vitamin $D$ is the suggested treatment method for cases with persistent HPT; however, hypercalcemia limits its usage. ${ }^{[5]}$ Following transplantation, parathyroidectomy (PTX) is the preferred choice of treatment because nodular hyperplasia of the parathyroid glands shows monoclonality and aggressive proliferation that is resistant to medical therapy. ${ }^{[6]}$

If hypercalcemia is refractory to medical treatment for more than a year following transplantation, PTX is the best choice of treatment. ${ }^{[7]}$

On the other hand, there are controversial opinions for consequences of PTX. After PTX, a decrease in kidney function may be observed after transplantation. ${ }^{[8]}$ However, Tseng et al. ${ }^{[9]}$ did not confirm this deterioration following surgery.

The aim of the present study was to analyze the effects of PTX on parathyroid hormone (PTH), phosphorus, and calcium concentrations as well as its impact on kidney function. 


\section{MATERIAL AND METHODS}

We retrospectively evaluated renal transplant recipients who had undergone PTX due to HPT after transplantation between January 2014 and January 2017. Demographic data, such as age, gender, type of dialysis, time on dialysis, time of PTX after transplantation, immunosuppressive treatment applied, and usage of vitamin D or cinacalcet, were obtained from medical records. We checked the blood concentrations of PTH, calcium, phosphorus, and estimated glomerular filtration rate (eGFR) before PTX and at postoperative first month, first year, and the last record of follow-up. The Chronic Kidney Disease Epidemiology Collaboration formula is used to determine eGFR. PTH is measured as intact PTH (reference range: $10-65 \mathrm{pg} / \mathrm{mL}$ ).

The SPSS 17.0 package program was used for statistical analysis. Continuous variables were expressed as median.

Table I. Demographic and clinical characteristics of kidney transplantation patients who underwent PTX

\section{$n=9$}

Age, years (median)

Dialysis vintage, years (median)

Immunosuppressive regimen ( $\mathrm{n}, \%)$

Containing TAC

Containing CsA

Containing everolimus
Time from transplantation to surgery,

month

$33.67(5-64)$

Use of cinacalcet, $n$ (\%)

$2(22.2)$

PTH level at the time of

transplantation, $\mathrm{pg} / \mathrm{mL}$ (median)

$887.33(475-1378)$

Calcium level before surgery $(\mathrm{mg} / \mathrm{dL})$

$11.02(9.8-12.6)$

Phosphorus level before

surgery $(\mathrm{mg} / \mathrm{dL})$

$2.35(1.7-3)$

PTH level before surgery $(\mathrm{pg} / \mathrm{mL})$

$311.57(102.8-685.3)$

TAC: Tacrolimus; CsA: Cyclosporin A; PTH: Parathyroid hormone.
Wilcoxon rank test was used for comparison of calcium, phosphorus, PTH, and eGFR before and after PTX. A pvalue $<0.05$ was considered statistically significant.

\section{RESULTS}

The mean age of two female and seven male patients was 51.78 (44-64) years.

Between January 2014 and December 2017, 9 out of 154 renal transplant patients underwent PTX due to persistent HPT. The rate of PTX in our transplant clinic was found to be $5.8 \%$ during the study. Renal replacement therapy before transplantation was hemodialysis for all patients.

The median period of dialysis prior to renal transplantation was $9.56(5-13)$ years.

The median time for parathyroid surgery after renal transplantation was 34 (5-64) months (Table I).

The method of surgery was subtotal PTX.

The median pre-operative values were 311.57 (102.8685.3) $\mathrm{pg} / \mathrm{mL}$ for intact PTH, II.02 (9.8-12.6) $\mathrm{mg} / \mathrm{dL}$ for calcium, $2.35 \mathrm{mg} / \mathrm{dL}$ for phosphorus, and 90.88 (50-14l) $\mathrm{ml} / \mathrm{min}$ for eGFR. One month after surgery, PTH (3II.57 vs. $147.5 \mathrm{pg} / \mathrm{mL}, \mathrm{p}=0.015$ ), calcium (II.02 vs. $9.01 \mathrm{mg} /$ $\mathrm{dL}, \mathrm{p}=0.017)$, and eGFR levels $(90.88$ vs. $75.44 \mathrm{ml} / \mathrm{min}$, $\mathrm{p}=0.008)$ decreased, and phosphorus ( 2.35 vs. $3.4 \mathrm{mg} /$ $\mathrm{dL}, \mathrm{p}=0.06$ ) increased compared with pre-PTX levels. There were a decrease in PTH (311.57 vs. $134.54 \mathrm{pg} / \mathrm{mL}$, $\mathrm{p}=0.008$ ), calcium ( 11.02 vs. $9.56 \mathrm{mg} / \mathrm{dL}, \mathrm{p}=0.038$ ), and eGFR levels ( 90.88 vs. $81.55 \mathrm{~mL} / \mathrm{min}, p=0.1 \mathrm{I})$ and an increase in phosphorus ( $2.35 \mathrm{vs} .3 .06 \mathrm{mg} / \mathrm{dL}, \mathrm{p}=0.038)$ I year after surgery.

There were a decrease in PTH (3II.57 vs. $112.2 \mathrm{pg} / \mathrm{mL}$, $p=0.008$ ), calcium ( $1 \mathrm{l} .02$ vs. $9.5 \mathrm{I} \mathrm{mg} / \mathrm{dL}, \mathrm{p}=0.02 \mathrm{I})$, and eGFR ( 90.88 vs. $79.39 \mathrm{~mL} / \mathrm{min}, \mathrm{p}=0.06$ ) levels and an increase in phosphorus ( 2.35 vs. $2.82 \mathrm{mg} / \mathrm{dL}, \mathrm{p}=0.08)$ at the end of follow-up. eGFR was found to decrease significantly I month following PTX. It was observed that this decrease was reversed after I year of follow-up (Table 2).

A decrease in eGFR $(p=0.066)$ and an increase in serum phosphorus $(p=0.08)$ were not found to be statistically sig-

Table 2. Calcium, phosphorus, PTH, and eGFR levels before and after PTX

\begin{tabular}{lcccc}
\hline & Pre-PTX & I month level/p value & I year level/p value & End of follow-up level/p value \\
\hline Calcium $(\mathrm{mg} / \mathrm{dL})$ & 11.02 & $9.01 / 0.017$ & $9.56 / 0.038$ & $9.51 / 0.021$ \\
Phosphorus $(\mathrm{mg} / \mathrm{dL})$ & 2.35 & $3.4 / 0.066$ & $3.06 / 0.038$ & $2.82 / 0.08$ \\
PTH $(\mathrm{pg} / \mathrm{mL})$ & 311.75 & $147.5 / 0.015$ & $134.54 / 0.008$ & $112.2 / 0.008$ \\
eGFR $(\mathrm{mL} / \mathrm{min})$ & 90.88 & $90.88 / 0.008$ & $81.55 / 0.11$ & $79.39 / 0.066$ \\
\hline
\end{tabular}


nificant at the end of the follow-up period. Calcium and PTH levels were found to be significantly decreased at the end of follow-up ( $p=0.02 \mathrm{I}$ and $p=0.008$, respectively.

During follow-up time, three patients relapsed and were administered cinacalcet.

\section{DISCUSSION}

In case of HPT following renal transplantation, successful PTX prevents various consequences of prolonged hypercalcemia and improves symptoms of established complications, as well. ${ }^{[1, I I]}$

In the current analysis, PTH and calcium levels decreased significantly, and phosphorus levels were normalized in the long term following PTX. Stabilizing normal serum calcium levels positively affects allograft survival. ${ }^{[12]}$ Therewithal, cessation of loss of phosphorous in urine due to PTH results in increase in bone mineral density. ${ }^{\left[{ }^{[3]}\right.}$ Although PTX is thought to play a role in graft protection, ${ }^{[14]}$ Garcia et al. ${ }^{[8]}$ suggested that PTX itself has a deteriorating effect on allograft function, resulting in allograft dysfunction in the long term.

The reason of renal allograft function deterioration following PTH is unclear. However, acute decrease in serum PTH following PTX may cause a decrease in kidney perfusion. PTH plays a role on kidney blood flow and glomerular filtration rate. It has an important role in both preglomerular vasodilatation and efferent vasoconstriction. ${ }^{[15]}$

Finding out how acute deterioration of renal function occurs shortly after PTX may enable better selection of the right cases. ${ }^{[16]}$

Consistently, we observed a significant decrease in eGFR at the first month following PTX in transplant recipients; however, eGFR approaches to presurgery levels I year after PTX. Deterioration of renal function at the last follow-up visit was statistically insignificant compared with baseline. This suggests that deterioration persists only for a short term. Schwarz et al. ${ }^{[17]}$ showed that higher PTH levels prior to PTX and total PTX with autotransplantation are significant predictors of kidney allograft deterioration in 76 cases. Schlosser et al. ${ }^{[18]}$ also reported that factors including decreased renal function during PTX and total PTX rather than subtotal PTX increase the incidence of allograft function deterioration. In our study, PTX type was subtotal PTX. Longer dialysis treatment is thought to increase the possibility of tertiary HPT. ${ }^{[19]}$ In our analysis, the duration of dialysis prior to transplantation was 9.56 years.

PTX has a negative hemodynamic effect on renal perfusion. This may be more important in the first year because calcineurin inhibitor-induced renal vasoconstriction is prominent, ${ }^{[20]}$ and acute rejection may occur.
HPT following renal transplantation improves gradually in the first year of transplantation, ${ }^{[1]}$ and early post-transplant PTX increases the risk of renal allograft dysfunction. For this reason, PTX may be delayed for I year after transplantation. During this period, cinacalcet is administered. Late post-transplant PTX is not expected to have a detrimental effect on kidney function. ${ }^{[2]]}$ Cruzado et al. ${ }^{[22]}$ reported that PTX is better than cinacalcet in normalizing blood calcium concentrations and PTH levels.

Three patients were found to have recurrent HPT in the long-term follow-up and were treated with cinacalcet.

Since our study was performed with a small number of retrospective patients, future prospective studies should be conducted to further elucidate the relationship between PTX and eGFR.

\section{CONCLUSION}

In HPT after renal transplantation, PTX decreases GFR level at I month but does not cause deterioration of GFR level in the long term. For this reason, PTX is a safe procedure for HPT after renal transplantation.

Ethics Committee Approval

This was a retrospective study, therefore no ethics committee approval was taken.

Informed Consent

Retrospective study.

Peer-review

Internally peer-reviewed.

Authorship Contributions

Concept: E.P.; Design: E.P.; Data collection \&/or processing: E.P., M.M.; Analysis and/or interpretation: E.P., S.F.Y.; Literature search: O.A., A.B.H.; Writing: E.P.; Critical review: Z.B.B.

Conflict of Interest

None declared.

\section{REFERENCES}

1. Evenepoel P, Claes K, Kuypers D, Maes B, Bammens B, Vanrenterghem $\mathrm{Y}$. Natural history of parathyroid function and calcium metabolism after kidney transplantation: a single-centre study. Nephrol Dial Transplant 2004;19:1281-7. [CrossRef]

2. Messa P, Sindici C, Cannella G, Miotti V, Risaliti A, Gropuzzo M, et al. Persistent secondary hyperparathyroidism after renal transplantation. Kidney Int 1998;54:1704-13. [CrossRef]

3. D'Alessandro AM, Melzer JS, Pirsch JD, Sollinger HW, Kalayoglu $\mathrm{M}$, Vernon WB, et al. Tertiary hyperparathyroidism after renal transplantation: operative indications. Surgery 1989;106:1049-56.

4. Kandil E, Florman S, Alabbas H, Abdullah O, McGee J, Noureldine $\mathrm{S}$, et al. Exploring the effect of parathyroidectomy for tertiary hyperparathyroidism after kidney transplantation. Am J Med Sci 
2010;339:420-4. [CrossRef]

5. Kasiske BL, Zeier MG, Chapman JR, Craig JC, Ekberg H, Garvey $\mathrm{CA}$, et al: Improving Global Outcomes. KDIGO clinical practice guideline for the care of kidney transplant recipients: a summary. Kidney Int 2010;77:299-311. [CrossRef]

6. Tominaga Y, Kohara S, Namii Y, Nagasaka T, Haba T, Uchida K, et al. Clonal analysis of nodular parathyroid hyperplasia in renal hyperparathyroidism. World J Surg 1996;20:744-52. [CrossRef]

7. Kinnaert P, Nagy N, Decoster-Gervy C, De Pauw L, Salmon I, Vereerstraeten P. Persistent hyperparathyroidism requiring surgical treatment after kidney transplantation. World J Surg 2000;24:13915. [CrossRef]

8. Garcia A, Mazuecos A, Garcia T, Gonzalez P, Ceballos M, Rivero M. Effect of parathyroidectomy on renal graft function. Transplant Proc 2005;37:1459-61. [CrossRef]

9. Tseng PY, Yang WC, Yang CY, Tarng DC. Long-term Outcomes of Parathyroidectomy in Kidney Transplant Recipients with Persistent Hyperparathyroidism. Kidney Blood Press Res 2015;40:386-94.

10. Schlosser K, Zielke A, Rothmund M. Medical and surgical treatment for secondary and tertiary hyperparathyroidism. Scand J Surg 2004;93:288-97. [CrossRef]

11. Milas M, Weber CJ. Near-total parathyroidectomy is beneficial for patients with secondary and tertiary hyperparathyroidism. Surgery 2004;136:1252-60. [CrossRef]

12. Gwinner W, Suppa S, Mengel M, Hoy L, Kreipe HH, Haller $\mathrm{H}$, et al. Early calcification of renal allografts detected by protocol biopsies: causes and clinical implications. Am J Transplant 2005;5:1934-41. [CrossRef]

13. Weisinger JR, Carlini RG, Rojas E, Bellorin-Font E. Bone disease after renal transplantation. Clin J Am Soc Nephrol 2006;1:1300-13.
14. Ozdemir FN, Afsar B, Akgul A, Usluoğullari C, Akçay A, Haberal M. Persistent hypercalcemia is a significant risk factor for graft dysfunction in renal transplantation recipients. Transplant Proc 2006;38:480-2. [CrossRef]

15. Massfelder T, Parekh N, Endlich K, Saussine C, Steinhausen M, Helwig JJ. Effect of intrarenally infused parathyroid hormone-related protein on renal blood flow and glomerular filtration rate in the anaesthetized rat. Br J Pharmacol 1996;118:1995-2000. [CrossRef]

16. Montenegro F, Ferreira G, Ianhez L. Surgical treatment of tertiary hyperparathyroidism: the choice of procedure matters! World J Surg 2008;32:1892-3. [CrossRef]

17. Schwarz A, Rustien G, Merkel S, Radermacher J, Haller H. Decreased renal transplant function after parathyroidectomy. Nephrol Dial Transplant 2007;22:584-91. [CrossRef]

18. Schlosser K, Endres N, Celik I, Fendrich V, Rothmund M, Fernández ED. Surgical treatment of tertiary hyperparathyroidism: the choice of procedure matters! World J Surg 2007;31:1947-53. [CrossRef]

19. Apaydin S, Sariyar M, Erek E, Ataman R, Yiğitbaş R, Hamzaoğlu I, et al. Hypercalcemia and hyperparathyroidism after renal transplantation. Nephron 1999;81:364-5. [CrossRef]

20. Naesens M, Kuypers DR, Sarwal M. Calcineurin inhibitor nephrotoxicity. Clin J Am Soc Nephrol 2009;4:481-508. [CrossRef]

21. Jeon HJ, Kim YJ, Kwon HY, Koo TY, Baek SH, Kim HJ, et al. Impact of parathyroidectomy on allograft outcomes in kidney transplantation. Transpl Int 2012;25:1248-56. [CrossRef]

22. Cruzado JM, Moreno P, Torregrosa JV, Taco O, Mast R, GómezVaquero C, et al. A Randomized Study Comparing Parathyroidectomy with Cinacalcet for Treating Hypercalcemia in Kidney Allograft Recipients with Hyperparathyroidism. J Am Soc Nephrol 2016;27:2487-94. [CrossRef]

\section{Böbrek Nakli Sonrası Paratiroidektomi: Tek Merkez Deneyimi}

Amaç: Başarılı böbrek transplantasyonundan sonra bile, alıııların \% 10-50'sinde kalıcı hiperparatiroidi görülebilir. Paratiroidektominin (PTX) böbrek fonksiyonlarında ve graft sağkalımında bozulma ile ilişkili olduğu bildirilmiştir. Çalışmamızda, merkemizde takip edilen ve PTX uygulanan böbrek nakli hastalarında PTX'in kalsiyum, fosfor, parathormon (PTH), tahmini glomerüler filtrasyon hızına (eGFR) uzun dönem etkilerini geriye dönük olarak değerlendirmeyi amaçladık.

Gereç ve Yöntem: Ocak 20I4-Aralık 2017 tarihleri arasında takip edilen I54 olgudan dokuzuna PTX uygulanmıştı. PTX öncesi ve sonrası medyan PTH, kalsiyum, fosfor ve eGFR değerleri kaydedildi.

Bulgular: Paratiroidektomi öncesi medyan PTH, kalsiyum, fosfor ve eGFR değerleri sırasıyla $311.57 \mathrm{pg} / \mathrm{mL}, 11.02 \mathrm{mg} / \mathrm{dL}, 2.35 \mathrm{mg} / \mathrm{dL}$ ve $90.88 \mathrm{~mL} / \mathrm{dk}$ idi. Bazal değerler ile bir aylık kontrol değerleri karşılaştıııldığında PTH (3II.5 pg/mL vs. $147.5 \mathrm{pg} / \mathrm{mL}, \mathrm{p}=0.015)$, kalsiyum (I I.02 $\mathrm{mg} / \mathrm{dL}$ vs. $9.01 \mathrm{mg} / \mathrm{dL}, \mathrm{p}=0.017)$ ve eGFR $(90.88 \mathrm{~mL} / \mathrm{dk}$ vs.75.44 mL/dk, $\mathrm{p}=0.008)$ değerlerinde azalma, fosfor seviyerinde artma $(2.35 \mathrm{vs} 3.4$ $\mathrm{mg} / \mathrm{dL}, \mathrm{p}=0.06)$ görüldü. Bir yıllık konrolde eGFR bazal seviyelerine döndü $(90.88 \mathrm{~mL} / \mathrm{dk}$ vs. $79.39 \mathrm{~mL} / \mathrm{dk}, \mathrm{p}=0.1 \mathrm{l})$.

Sonuç: Böbrek nakli sonrası PTX uygulanması güvenilir bir metoddur. Her ne kadar PTX sonrası böbrek fonksiyonlarında erken dönemde bozulma görülse de, uzun dönemde stabilizasyon sağlanır.

Anahtar Sözcükler: Böbrek nakli; kalsiyum; paratiroidektomi. 